\title{
Urban Recreational Fisheries in the Australian Coastal Zone: The Sustainability Challenge
}

\author{
Daryl P. McPhee
}

Faculty of Society and Design, Bond University, Robina, QLD 4228, Australia; dmcphee@bond.edu.au; Tel.: +61-7-5595-0155

Academic Editor: Iain Gordon

Received: 1 December 2016; Accepted: 11 February 2017; Published: 13 March 2017

\begin{abstract}
Recreational fishing is an important wildlife harvesting activity in urban coastal areas, and recreational harvest in these areas can frequently exceed the commercial harvest. Recreational fishing is a key way that many members of the public experience the environment. The activity enhances social capital, promotes respect for nature, provides health benefits and can provide economic benefits to coastal communities. It is also an important driver of the science on aquatic animals and habitats, and an important tangible reason for many members of the public to conserve and protect aquatic resources. Overall, there has been little specific consideration of urban recreational fisheries management in Australia, despite the paramount importance of urban areas as a focus of recreational fishing activity. This paper identifies that in order to maximize individual and societal benefits from recreational fishing, there needs to be a refocussing of management with the aim of being more holistic. Historically, fisheries management in Australia has focused on maximum sustainable yield (MSY) or maximum economic yield (MEY) which is relevant for the commercial fishing sector, but neither of these is directly relevant to recreational fisheries. This paper identifies that Urban Fisheries Management Plans are required that recognize the specific issues associated with urban recreational fisheries. These plans need to coordinate within and between levels of government and have clear management objectives relevant to urban recreational fisheries. Enhanced opportunities for meaningful citizen science can be incorporated at multiple levels within these plans and this can engender public support for environmental stewardship, as well as fill a very important gap in the knowledge base necessary for managing the activity. As urban recreational fisheries are often occurring in highly modified or degraded habitats, a central element of these plans needs to be habitat restoration and this can have broader benefits for aquatic health. Other management tools include habitat creation (e.g., artificial reefs), optimization of coastal infrastructure as fisheries habitat, and stock enhancement. Overall, Urban Fisheries Management Plans represent a necessary evolution of fisheries management to better address the specific challenges of urban recreational fisheries management, and to best ensure that benefits are optimised.
\end{abstract}

Keywords: recreational fishing; angling; citizen science; fisheries enhancement; urban planning; coastal management; leisure sciences

\section{Introduction}

Urbanization is a dominant demographic trend and a rapidly growing form of land use change. Coastal urban recreational fisheries are those that occur adjacent to large coastal population centres such as capital cities and major regional cities. The dominant land uses are typically central business districts surrounded by extensive residential developments, and infrastructure that supports these activities. Urban recreational fisheries are prominent along the coasts of North America, Australia and Europe. The recognition of their importance in Asia is being realized, particularly in China [1,2]. 
Recreational fishing is an important wildlife harvesting activity in urban coastal areas. In these areas, the volume of the recreational catch often exceeds the commercial catch, or is the only fishing activity that occurs [3]. By nature, recreational fisheries are open access-an as of right activity. However, it is controlled by management arrangements which limits the activity to certain fishing gear types (e.g., hook and line), and frequently controls the size at which an individual animal can be retained (minimum and/or maximum legal sizes), and the number of fish that an individual may retain (bag limits) [4]. Contemporary thinking is that the management of recreational fisheries needs to extend beyond the traditional models based on fisheries biology, to an ecological-social approach as it involves ecosystems, natural living resources, humans and institutions such as government management agencies [5-7].

While recreational fishing has always been an Australian pastime, the need for its incorporation in fisheries management only emerged in the late 1990s [3] and this is a trend mirrored overseas [8-13]. Recreational fishing is a key way that many members of the public experience the coastal and marine environment. It enhances social capital, promotes respect for nature and provides health and economic benefits [14]. However, urbanization is known to reduce the interest of urban residents in consumptive outdoor recreation activities, such as recreational fishing, and this can have implications for participation rates in recreational fishing overall $[5,15,16]$.

Much of the global focus on understanding urban fisheries and urban fisheries management has been in freshwater areas ([17] for example), although some work has been focused in coastal areas $[13,18,19]$. Overall, there has been little consideration of the specific management needs for urban recreational fisheries in Australia. In particular, the importance of recreational fishing has not been incorporated in urban planning considerations despite the public importance of the activity. In this paper, the case for managing urban fisheries as a specific subset of fisheries management with specific goals, actions and management interventions is made. This requires a rethink of what constitutes "sustainability" in the context of an urban coastal recreational fishery and what tools and approaches are needed to achieve it. This paper highlights the potential societal and conservation benefits of having urban recreational fisheries that meet the needs of the urban community.

\section{Recreational Fisheries and Australian Urban Coastal Fisheries in Context}

Recreational fishing typically involves angling (hook and line), but may also involve spearfishing, the use of small traps to catch animals such as crabs, or small nets to catch bait [20]. Recreational fisheries differ substantially from commercial fisheries. The primary focus of commercial fisheries is to profitably supply seafood to consumers. As such, it operates in a traditional commodity market and depending on the commercial fishery; this commodity market may be global in nature. Recreational fishing on the other hand is an outdoor experience and does not occur in a traditional commodity market, although expenditure by recreational fishers on their fishing activities can be substantial [21].

The reasons that an individual undertakes recreational fishing are diverse and include various catch and non-catch related motivations, the latter include "being outdoors" and "being with friends and family". For the majority of recreational fishers, non-catch related motivations are the primary reason for undertaking the activity, although the possibility of catching a fish is still a consideration as evidenced by catch rates being an important determinant of angling quality [22]. The importance of catch-related motivations can be greater for avid recreational fishers compared to very occasional fishers [23], but even among more avid anglers who value catch-related motivations, there can be substantial differences. Many avid recreational fishers may use their catch as a regular source of fresh protein; while others practice catch and release for all of their catch.

Urban recreational fisheries typically occur in a highly modified environment with limited and fragmented natural intact shoreline and habitats present. Intertidal areas may be greatly reduced by reclamations and shoreline protection structures, and vegetated habitats such as seagrass beds may be greatly reduced in area and/or highly fragmented due to a range of impacts including from poor water quality or direct removal $[24,25]$. Water quality in urban areas can be highly impacted by pollutants to 
the extent that consuming seafood from parts of these waterways is not recommended from a human health perspective [19]. This is the case for the upper reaches of Sydney Harbour. These impacts occur as a result of urban development itself, as well as potentially from upstream agricultural land use (e.g., the Lockyer Valley west of Brisbane) that produces food for urban areas. Overall, these impacts act in a cumulative fashion and the responsibilities for managing these impacts are fragmented across levels of government and within levels of government.

On average across the industrialized world, about $10.5 \%$ of the population are recreational fishers [26]. Participation numbers and participation rates in each of the major Australian coastal capital cities are shown in Table 1 . The participation numbers represent where an angler resides rather than where he actually fishes, but it is demonstrated empirically that most recreational fishers in urban environments predominantly fish close to their residence [18].

Table 1. The number of recreational fishing participants and participation rates at six large coastal cities in Australia.

\begin{tabular}{ccccc}
\hline Region & $\begin{array}{c}\text { Number of Recreational } \\
\text { Fishing Participants }\end{array}$ & $\begin{array}{c}\text { Participation } \\
\text { Rate (\%) }\end{array}$ & $\begin{array}{c}\text { Year(s) Data } \\
\text { Collected }\end{array}$ & Reference \\
\hline Sydney (NSW) & 375,558 & 8.6 & $2013-2014$ & {$[27]$} \\
Brisbane (Queensland) & 259,831 & - & 2010 & {$[28]$} \\
Melbourne (Victoria) & 321,051 & 10.2 & $2000-2001$ & {$[29]$} \\
Perth (Western Australia) & 301,949 & 24.1 & $2000-2001$ & {$[29]$} \\
Hobart (Tasmania) & 41,906 & 21.9 & $2012-2013$ & {$[30]$} \\
Adelaide (South Australia) & 145,269 & 16.2 & $2007-2008$ & {$[31]$} \\
\hline
\end{tabular}

\section{Why Urban Fisheries Matter}

Recreational fishing is an important driver of the science on aquatic animals and habitats and an important tangible reason beyond intrinsic environmental values for conservation and/or rehabilitation of aquatic systems [32]. In the United States for example, salmon fishing is a significant reason for the restoration of aquatic habitats that support salmon, and these restoration efforts provide benefits for the aquatic ecosystems as a whole when undertaken appropriately [33,34]. Given that the number of urban recreational fishers is typically large; the magnitude of the impetus for positive environmental change can be significant. Conservation actions and management efforts (including restoration) are generally enhanced when community members value the natural resource to be protected or rehabilitated, and when they ultimately benefit (directly or indirectly) from these actions and efforts. Recreational fishers may also provide an early warning sign of a significant local environmental event such as a chemical spill, a fish kill or the appearance of an invasive marine species.

For individuals, recreational fishing in urban areas can promote physical activity, restorative and stress-alleviating experiences, and social interaction and cohesion [35-38]. Indeed, in the later part of the 19th Century, getting out into nature was a standard medical treatment for dealing with issues, such as emotional distress and mental exhaustion [39]. For children, it provides opportunity to avoid "nature deficit disorder"- - the disconnection with the environment that stems from the current generation's tendency to focus on built and engineered environments and digital entertainment, rather than the natural world. It also provides an activity in which children can actively engage with other family members and other adults, thus building and enhancing generational bonds. Children exposed to nature care about such areas when they grow up and environmentally responsible behaviour stems from contact with the environment [40,41]. Further, recreational fishing represents an outdoor pastime where disabled or less mobile people can easily participate (providing appropriate infrastructure exists). The social and self-improvement benefits associated with recreational fishing for fishers with disabilities are high [42]. Although not well explored to date, it also provides an important potential avenue for Aboriginal youth in urban areas to culturally engage or re-engage with sea country. 
Recreational fishing can generate substantial economic activity, and while economic activity in urban areas is diverse and frequently high, it nonetheless represents an activity that supports businesses at the local level (e.g., bait and tackle stores and fishing charter businesses).

\section{Sustainability in Coastal Urban Recreational Fisheries-Concepts and Challenges}

In Australia, fisheries sustainability is based on Ecological Sustainable Development (ESD) [20]. While sustainability of the stock and the ecosystem that supports it is paramount, within this management paradigm, a range of social and economic objectives are present which are of relevance to urban recreational fisheries. These generically include objectives related to "providing community benefit", "provide for utilization by the community" and "sharing fisheries resources". In NSW, South Australia and Victoria, there are legislative objectives specifically focused on promoting recreational fishing opportunity [20]. While there is no need for legislation at the state level to have explicit objectives focused on the management of urban recreational fisheries, the legislation does clearly include objectives beyond biological sustainability, and thus enable tailored management strategies and the application of management tools for a diverse range of circumstances-including urban recreational fisheries management. However, in reality, much of fisheries management in Australia remains focused on biological aspects of harvested stocks.

A number of authors have previously identified that a rethink of recreational fisheries management is required given the social dimensions of the activity $[6,43,44]$. Historically, fisheries management has focused on commercial fisheries with the concepts of either maximum sustainable yield (MSY) or more recently maximum economic yield (MEY) as the cornerstone. These concepts are often applied at the "unit stock" level. This is understandable from a biological perspective; however these concepts are not necessarily the most relevant approaches for recreational fisheries in general. A unit stock may be above a specific biomass target; however local depletions may have an important impact on recreational fishing satisfaction (particularly for avid fishers). Such depletions though may not manifest themselves as being important from a biological perspective across the unit stock. Also, a lack of physical access to fish stocks either through privatization of land for residential or commercial purposes or on-water access restrictions (e.g., for security around ports) may see a stock remain well within MSY, but not deliver optimal community benefit. In terms of MEY, as recreational fisheries are open access and do not occur in a true market, the concept of MEY is not relevant. The key management outcome from recreational fishing is satisfaction with the recreational fishing experience, and this is a parameter that can potentially be measured through empirical data collection.

In rethinking the management of urban recreational fisheries and how it differs from the management of commercial fisheries, understanding fishing "effort" is important. For commercial fisheries, it is desirable theoretically to catch the most fish for the least amount of fishing effort. In simple terms, the catch is the income and the effort is the cost. This is not the case for a recreational fishing where ideally participation (effort) should be high for overall benefits to the community to be realized. While a high participation level is important for recreational fishing, it can lead to overcrowding which can negatively impact the overall angling experience, as it can in other leisure activities [45]. However, it is possible that recreational fishers in an urban area are more tolerant up to a point of crowding than they are in regional or remote areas as their expectations of the number of other recreational fishers likely to be present on a given day may differ. Unlike commercial fisheries, fishing effort (participation) in a recreational fishery can increase without a substantial increase in retained catch given that the product from recreational fishing is an outdoor experience, the majority of fishers do not catch fish, and a considerable proportion of avid fishers practice (wholly or partly) catch and release. Nonetheless, the magnitude of the overall recreational catch still needs to be considered, but it should not be assumed to have the same dynamic as that of commercial fisheries. 


\section{Meeting the Urban Recreational Fishing Challenge-Planning and Management}

The management of recreational fisheries has lagged behind that of commercial fisheries, and given the specific circumstances associated with urban coastal recreational fisheries in Australia, a rethink of management strategies for these important recreational fisheries is required. While there is a very clear and necessary role for typical fisheries management tools such as minimum legal sizes and recreational bag limits to continue to be applied, these methods alone cannot deliver holistic management necessary for urban recreational fisheries that provide optimal benefits. Further, they do not in isolation guarantee that a recreationally fished species does not decline in abundance significantly [46].

What is needed are Urban Recreational Fisheries Management Plans (URFMP) for each of the coastal capital cities in Australia. In developing these plans, there needs to be participation by the recreational fishing sector in their development through appropriate forums. Recreational fisheries management measures have generally focused at a jurisdictional (State) level. While this can be justified in many instances in terms of consistency and cost-effectiveness, the differences inherent (and issues faced) in an urban recreational fishery as opposed to those in more regional or remote areas are substantially different. These plans need to have specific objectives tailored to urban recreational fisheries, and integrate across relevant government Departments and across levels of government in order to deliver holistic management. Overall, such a holistic approach is consistent with an ecosystem based approach to fisheries management [47], and consistent with considering recreational fisheries as a complex and adaptive social-ecological system [7].

As discussed in this paper, the typical fisheries management objectives of MSY and MEY are not of direct relevance to recreational fisheries. Unlike commercial fisheries where effort needs to be constrained through management actions, high recreational fishing effort (participation) can be a potential management goal. Consistent with an MSY approach, recreational fisheries management has generally focused on constraining harvest, and this focus should not be substantially diluted, but management needs to focus more on understanding the recreational fishing experience and the development of clear objectives to optimize the benefits.

The need for coordination between agencies and levels of government to achieve improved natural resource outcomes when challenges involve a complex problem with a large number of stakeholders is established [48]. Such challenges cannot be addressed completely by single-level approaches to policy, planning and implementation [48,49]. In the case of urban recreational fisheries in Australia, there is a need to extend the management approach beyond typical fisheries approaches and tools, and conservation legislation (e.g., marine parks) that is more focused on pristine areas. In particular, local governments need to be better incorporated into fisheries management in urban areas as they influence access such as the setting aside of parkland, parking; and important infrastructure such as boat ramps, as well as managing a range of impacts that potentially impact water quality. It can be a source of frustration for recreational fishing stakeholders when fisheries management planning is constrained to only addressing issues within a fisheries portfolio and not addressing issues which affect access to the fisheries resource, and carrying capacity and health of the environment that supports fisheries production as a whole.

In the case of improving marine and estuarine water quality in urban embayments, there has been substantial success in a holistic and integrated approach to management that has resulted in long-term positive change in Australia. The Brisbane River and Moreton Bay Study, an interdisciplinary study of Moreton Bay and its major tributaries, was initiated to address water quality issues in that region. The study was established in 1994 by six local councils in association with two state departments and also obtained funding from the Commonwealth government [50]. As such, the study could lay claim to being supported by all three layers of government in Australia. Participation by the community, local council and state government in the process ensured that the scientific recommendations were implemented and also ensured that the scientific tasks appropriately prioritized and targeted the major issues [50,51]. Far from being a study that represented a snapshot in time, it gave rise to the 
Moreton Bay Waterways and Catchments Partnership (Healthy Waterways), which continues to drive ongoing research and improvements to water quality [52]. An integrated approach to managing urban recreational fisheries in Australia, similar to the example of the Moreton Bay Waterways and Catchments Partnership (Healthy Waterways) could be developed and implemented.

Specifically, an URFMP should address habitat restoration (or creation), stock enhancement, fishing access, citizen science opportunities and stock enhancement. Each of these issues are discussed further. Promotion of recreational fishing opportunities in the urban environment should also be a component of an URFMP as a means of recruiting recreational fishers to the fishery, including those that may have lapsed from undertaking the activity [16].

\subsection{Fishing Access}

Fishing access in urban environments is frequently highly constrained by cumulative loss through development. While such losses in access are generally not considered in recreational fisheries management, they can represent a direct and meaningful impact on recreational fishers. Substantial amounts of foreshore in an urban environment can be off limits to recreational fishers due to being developed as residential or commercial property. Further commercial shipping, port operations and passenger ferries can limit safe access to certain areas by boat based fishers. Currently, it is not possible to determine how much of the Australian urban area is restricted for recreational fishing-where it is not permitted or cannot be undertaken safely. An URFMP should map access constraints and determine how much area currently cannot be accessed, and set measurable goals to maintain access or enhance access where possible, within the constraints of multiple-use. Where future developments further reduce recreational fishing access, proponents of those developments should be required through statutory assessment and approval processes to offset that loss by improving access elsewhere or by other means. Offsets for biodiversity loss as a result of developments are common practice in Australia, and it is a logical extension to extend the concept to fishing access in urban areas as it allows new developments to still potentially proceed while positively addressing impacts to recreational fishing access.

\subsection{Citizen Science}

Citizen science represents a cost-effective approach to collecting fine-scale information for management purposes on the recreational fishing activities of avid fishers that can lead to improved understanding of the activities of this critical group of recreational fishers. Citizen science can also improve the public stewardship of the natural environment and be a substantial driver of, and man power for habitat restoration initiatives [53,54]. It is identified as being particularly important in urban areas [55]. Citizen science can be defined as scientific research and monitoring projects for which members of the public collect, categorize, transcribe or analyze scientific data [56]. Citizen science is generally underrepresented in the aquatic environments, and fisheries more specifically [57], despite it having substantial potential to cost-effectively monitor and collect information at a scale appropriate to better inform management [58]. Overall, monitoring of recreational fishing is generally undertaken with less frequency and rigour than commercial fishing [59], and citizen science represents a key way to address this deficiency in a cost-effective manner. It can also provide finer resolution information. The widespread use of smartphones (and apps) is an important emerging platform for recreational fishing data collection that will almost certainly grow in utility and importance [60,61]. Perhaps the best known example of citizen science within fisheries research are sportfish tagging programs which have a relatively long history and have facilitated substantial gains in knowledge of key species [62-65]. Citizen science can involve the monitoring of habitats such as seagrass which are important for harvested species, and the quality of such data when collected using structured survey designs and methods can be high quality [66]. 


\subsection{Habitat Restoration and Habitat Creation}

It is well acknowledged that priority should be on conserving habitats rather than restoring them after they have been impacted by human activities [67]. Restored habitats do not always contain similar fish communities to adjacent natural habitats [68]. However, in the context of urban environments, conserving habitats is not always an option, because in many cases the removal or change to these habitats commenced decades or even centuries ago [69]. The benefits of "good" restoration in support of urban recreational fisheries can extend to aquatic health in general. To be effective, habitat restoration must extend beyond just ongoing works and be undertaken within an adaptive management framework that includes clear objectives, appropriate site selection for those works, and monitoring and evaluation to ensure that objectives are met [70]. Further, restoration efforts must align with societal goals, otherwise conflict and failure can ensue [71]. Formally aligning restoration efforts with the desires of urban recreational fishers-a large social group can help achieve societal support.

While restoration efforts of coastal habitats has generally encompassed vegetated habitats such as mangrove, seagrass and saltmarsh, there is increasing focus on the need to restore oyster reefs as the scale of the loss has increasingly been realized, and the broader ecological role of this habitat in coastal systems understood. Oysters are important aquatic engineers that can structure entire ecosystems, providing hard structure, food and habitat for fish and invertebrates, filtration of phytoplankton, nutrient uptake and shoreline stabilization [72,73]. The global importance of biogenic reefs, such as oyster reefs, is now widely recognized [74]. However, $85 \%$ of oyster reef ecosystems globally have been lost over the past 130 years [73], and losses along the Australian coast are similar if not more [75,76]. These losses in Australia include areas adjacent to the urban centres of Sydney (e.g., Sydney Harbour and the Georges River), Brisbane (Moreton Bay) and Melbourne (Port Phillip Bay) [75,76] which are the focus of urban recreational fisheries. Oyster beds have been successfully restored in a number of locations, including the Great Wicomico River (WV, USA) [77], and numerous sites in the Gulf of Mexico [78], although success is not always guaranteed [77,79]. Restored oyster beds can enhance fisheries production [72] as well as fish diversity [80]. Restored oyster beds can also contribute substantially to the removal of nutrients from the water column [81,82], and excess nutrients is a consistent problem in urban waterways.

As well as habitat restoration, there is a potential opportunity for an engineering focus ("green engineering") to maximize the habitat benefits of urban infrastructure such as seawalls and other structures. These artificial habitats can represent novel environments, particularly when they are well designed. Simple and cost-effective structures that substantially increased the diversity and abundance of invertebrates that use sea walls as habitat in Sydney Harbour have been successfully trialed [83]. Similar positive results have been achieved elsewhere [84,85]. Although not tested to date, such enhancements can plausibly have flow on benefits to fisheries production.

Last, dedicated artificial reefs can be used to create habitat to support urban fisheries activities. Dedicated artificial reefs should be purpose built structures and not "materials of convenience" such as used tyres, and the area and orientation of their deployment should be planned to maximize benefits while not impinging on other users such as commercial shipping, or on natural habitats. In NSW, there is an artificial reef program that has seen large offshore reefs adjacent to urban areas deployed after a statutory environmental assessment which provided guidance into the materials and design, environmental impacts, and an adaptive management framework including detailed requirements for environmental monitoring. This holistic approach to artificial reef deployment maximizes the chance of success and minimizes unforeseen risks. There remains conjecture as to whether an artificial reef simply attracts fish and makes them easier to catch, or whether they actually increase production [86]. Overall, the most parsimonious explanation is that they can potentially do both. While the conservation or restoration of natural habitat types should remain paramount, there is a clear potential role for habitat creation through the use of artificial reefs in particular. 


\subsection{Stock Enhancement}

Stock enhancement has long been practiced in Australian freshwater areas for species such as Murray cod (Maccullochella peelii) and this has supported recreational fishing as well as conservation efforts [87]. Until relatively recently in Australia, there has been substantially less focus on stock enhancement in marine areas due to concerns about the cost-benefit of activities and potential environmental impacts associated with stocking, and the practical constraint of being able to hatchery rear sufficient numbers of juveniles of key angling species. NSW was the first state to propose large scale and ongoing stock enhancement of estuarine waters in Australia. For tools and criteria for choose where to stock, and what to stock with, as well as important approaches for managing key risks such as disease, stocking density and genetic integrity have been developed [88]. It represents a practical and holistic way to enhance urban recreational fisheries through a rigorous assessment approach that considers environmental issues alongside economic and social issues. While stock enhancement of urban fisheries should not replace the need for effective management of the activity, and should not replace the need to maintain or improve water quality and restore critical habitat, it does represent an additional tool that should be considered in the management of urban fisheries in Australia.

\section{Conclusions}

Overall, recreational fisheries are of substantial importance in Australian urban coastal cities where it represents a very popular leisure activity. Recreational fishers can be important drivers for improvements to urban coastal environments that are subjected to cumulative stressors. Typical fisheries management frameworks and management objectives are not optimal for recreational fisheries and in particularly urban recreational fisheries. Although a number of specific traditional fisheries management tools such as minimum legal sizes and gear restrictions remain relevant, they are insufficient however for the full benefits of recreational fishing to be realized. There are important issues that affect the fishery are outside of traditional fisheries management frameworks. Major Australian coastal cities should have specific Urban Fisheries Management Plans that recognize the specific issues associated with urban recreational fisheries. These plans should coordinate within and between levels of government and have clear management objectives relevant to urban fisheries. These plans need to incorporate opportunities where relevant for habitat restoration or habitat creation, as well as necessary infrastructure support can enhance the recreational fishing experience. Urban recreational fisheries represent a substantial catalyst for habitat restoration activities in particular, which can have wider benefits for aquatic conservation. Stock enhancement is also a relevant potential tool for urban fisheries management. Citizen science opportunities are significant within the scope of urban recreational fisheries and are a chance for stakeholders to take greater stewardship of the local resource and collect valuable monitoring information in a cost-effective manner. Overall, Urban Fisheries Management Plans are a substantial opportunity to make fisheries management more holistic and more focused on end user requirements without compromising the resource base.

Conflicts of Interest: The authors declare no conflict of interest.

\section{References}

1. Chen, Y. The importance of marine recreational fishing in Shanghai. In Proceedings of the Seventeenth Biennial Conference of the International Institute of Fisheries Economics and Trade, Brisbane, Australia, 7-11 July 2014.

2. Ping, Y. Recreational fisheries in China: Theories and Planning. In Proceedings of the Seventeenth Biennial Conference of the International Institute of Fisheries Economics and Trade, Brisbane, Australia, 7-11 July 2014.

3. McPhee, D.P.; Leadbitter, D.; Skilleter, G.A. Swallowing the bait: Is recreational fishing in Australia ecologically sustainable? Pac. Conserv. Biol. 2002, 8, 40-51. [CrossRef] 
4. McPhee, D. The management of recreational fisheries. In Marine Resources Management; Gullett, W., Schofield, C., Vince, J., Eds.; LexisNexis: Chatsworth, Australia, 2011.

5. Arlinghaus, R. Understanding recreational angling participation in Germany: Preparing for demographic change. Hum. Dimens. Wildl. 2006, 11, 229-240. [CrossRef]

6. Arlinghaus, R.; Cooke, S.J.; Sutton, S.G.; Danylchuk, A.J.; Potts, W.; Freire, K.; Alós, J.; Silva, E.T.; Cowx, I.G.; Anrooy, R. Recommendations for the future of recreational fisheries to prepare the social-ecological system to cope with change. Fish. Manag. Ecol. 2016, 23, 177-186. [CrossRef]

7. Arlinghaus, R.; Alós, J.; Beardmore, B.; Daedlow, K.; Dorow, M.; Fujitani, M.; Hühn, D.; Haider, W.; Hunt, L.M.; Johnson, B.M.; et al. Understanding and managing freshwater recreational fisheries as complex adaptive social-ecological systems. Rev. Fish. Sci. Aquac. 2017, 25, 1-41. [CrossRef]

8. Post, J.R.; Sullivan, M.; Cox, S.; Lester, N.P.; Walters, C.J.; Parkinson, E.A.; Paul, A.J.; Jackson, L.; Shuter, B.J. Canada's recreational fisheries: The invisible collapse? Fisheries 2002, 27, 6-17. [CrossRef]

9. Sutinen, J.G.; Johnston, R.J. Angling management organizations: Integrating the recreational sector into fishery management. Mar. Policy 2003, 27, 471-487. [CrossRef]

10. Arlinghaus, R.; Cooke, S.J. Global impact of recreational fisheries. Science 2005, 307, 1561-1563. [CrossRef] [PubMed]

11. Morales-Nin, B.; Moranta, J.; García, C.; Tugores, M.P.; Grau, A.M.; Riera, F.; Cerda, M. The recreational fishery off Majorca Island (western Mediterranean): Some implications for coastal resource management. ICES J. Mar. Sci. J. Cons. 2005, 62, 727-739. [CrossRef]

12. Cooke, S.J.; Cowx, I.G. Contrasting recreational and commercial fishing: Searching for common issues to promote unified conservation of fisheries resources and aquatic environments. Biol. Conserv. 2006, 128, 93-108. [CrossRef]

13. Ihde, T.F.; Wilberg, M.J.; Loewensteiner, D.A.; Secor, D.H.; Miller, T.J. The increasing importance of marine recreational fishing in the US: Challenges for management. Fish. Res. 2011, 108, 268-276. [CrossRef]

14. Young, M.A.; Foale, S.; Bellwood, D.R. Why do fishers fish? A cross-cultural examination of the motivations for fishing. Mar. Policy 2016, 66, 114-123. [CrossRef]

15. Hendee, J.C. Rural-urban differences reflected in outdoor recreation participation. J. Leis. Res. 1969, 1, 333-341.

16. Balsman, D.M.; Shoup, D.E. Opportunities for urban fishing: Developing urban fishing programs to recruit and retain urban anglers. Am. Fish. Soc. Symp. 2008, 67, 31-40.

17. Arlinghaus, R.; Mehner, T. A management-orientated comparative analysis of urban and rural anglers living in a metropolis (Berlin, Germany). Environ. Manag. 2004, 33, 331-344. [CrossRef] [PubMed]

18. Barrella, W.; Ramires, M.; Rotundo, M.M.; Petrere, M.; Clauzet, M.; Giordano, F. Biological and socio-economic aspects of recreational fisheries and their implications for the management of coastal urban areas of south-eastern Brazil. Fish. Manag. Ecol. 2016, 23, 303-314. [CrossRef]

19. Burger, J.; Pflugh, K.K.; Lurig, L.; Hagen, L.A.; Hagen, S. Fishing in Urban New Jersey: Ethnicity Affects Information Sources, Perception, and Compliance. Risk Anal. 1999, 19, 217-229. [CrossRef] [PubMed]

20. McPhee, D. Fisheries Management in Australia; Federation Press: Annandale, Australia, 2008; p. 257.

21. McPhee, D.P.; Hundloe, T.J.A. The role of expenditure studies in the (mis)allocation of access to fisheries resources in Australia. Australas. J. Environ. Manag. 2004, 11, 34-41. [CrossRef]

22. Holland, S.M.; Ditton, R.B. Fishing trip satisfaction: A typology of anglers. N. Am. J. Fish. Manag. 1992, 12, 28-33. [CrossRef]

23. Beardmore, B.; Haider, W.; Hunt, L.M.; Arlinhaus, R. The importance of trip context for determining primary angler motivations: Are more specialized anglers more catch-orientated than previously believed? N. Am. J. Fish. Manag. 2011, 31, 861-879. [CrossRef]

24. Abal, E.G.; Dennison, W.C. Seagrass depth range and water quality in southern Moreton Bay, Queensland, Australia. Mar. Freshw. Res. 1996, 47, 763-771. [CrossRef]

25. McLennan, M.; Sumpton, W. The distribution of seagrasses and the viability of seagrass transplanting in the Broadwater, Gold Coast, Queensland. Proc. R. Soc. Qld. 2005, 112, 31-38.

26. Arlinghaus, R.; Tillner, R.; Bork, M. Explaining participation rates in recreational fishing across industrialised countries. Fish. Manag. Ecol. 2015, 22, 45-55. [CrossRef]

27. West, L.D.; Stark, K.E.; Murphy, J.J.; Lyle, J.M.; Ochwada-Doyle, F.A. Survey of Recreational Fishing in New South Wales and the ACT, 2013/14; New South Wales Department of Primary Industries: Sydney, Australia, 2015. 
28. Taylor, S.; Webley, J.; McInnes, K. 2010 Statewide Recreational Fishing Survey; Queensland Department of Agriculture, Fisheries and Forestry: Brisbane, Australia, 2012.

29. Henry, G.W.; Lyle, J.M. The National Recreational and Indigenous Fishing Survey; Australian Government Department of Fisheries and Forestry: Canberra, Australia, 2003.

30. Lyle, J.M.; Stark, K.E.; Tracey, S.R. 2012-2013 Survey of Recreational Fishing in Tasmania; Institute for Marine and Antarctic Studies: Hobart, Australia, 2014.

31. Jones, K. South Australian Recreational Fishing Survey 2007/08; Series Paper No. 54; South Australian Fisheries Management: Adelaide, Australia, 2009.

32. Tufts, B.L.; Holden, J.; DeMille, M. Benefits arising from sustainable use of North America's fishery resources: Economic and conservation impacts of recreational angling. Int. J. Environ. Stud. 2015, 72, 850-868. [CrossRef]

33. Shreffler, D.K.; Simenstad, C.A.; Thom, R.M. Juvenile salmon foraging habitat in a restored estuarine wetland. Estuaries 1992, 15, 204-213. [CrossRef]

34. Simenstad, C.A.; Cordell, J.R. Ecological assessment criteria for restoring anadromous salmonid habitat in Pacific Northwest estuaries. Ecol. Eng. 2000, 15, 283-302. [CrossRef]

35. Berman, M.G.; Jonides, J.; Kaplan, S. The cognitive benefits of interacting with nature. Psychol. Sci. 2008, 19, 1207-1212. [CrossRef] [PubMed]

36. Johansson, M.; Henningsson, M. Social-psychological factors in public support for local biodiversity conservation. Soc. Nat. Resour. 2011, 24, 717-733. [CrossRef]

37. Hartig, T.; Mitchell, R.; De Vries, S.; Frumkin, H. Nature and health. Ann. Rev. Public Health 2014, 35, $207-228$. [CrossRef] [PubMed]

38. Korpela, K.; Borodulin, K.; Neuvonen, M.; Paronen, O.; Tyrväinen, L. Analyzing the mediators between nature-based outdoor recreation and emotional well-being. J. Environ. Psychol. 2014, 37, 1-7. [CrossRef]

39. Schuster, D.G. Neurasthenia and a modernizing America. JAMA 2003, 290, 2327-2328. [CrossRef] [PubMed]

40. Duda, M.D.; Bissell, S.J.; Young, K.C. Wildlife and the American Mind: Public Opinion on and Attitudes toward Fish and Wildlife Management; Responsive Management: Harrisonburg, VA, USA, 1998.

41. Hungerford, H.R.; Volk, T.L. Changing learner behavior through environmental education. J. Environ. Educ. 1990, 21, 8-21. [CrossRef]

42. Freudenberg, P.; Arlinghaus, R. Benefits and constraints of outdoor recreation for people with physical disabilities: Inferences from recreational fishing. Leis. Sci. 2009, 32, 55-71. [CrossRef]

43. Radomski, P.J.; Grant, G.C.; Jacobson, P.C.; Cook, M.F. Visions for recreational fishing regulations. Fisheries 2001, 26, 7-18. [CrossRef]

44. Malvestuto, S.P.; Hudgins, M.D. Optimum yield for recreational fisheries management. Fisheries 1996, 21, 6-17. [CrossRef]

45. Gramann, J.H. Toward a behavioral theory of crowding in outdoor recreation: An evaluation and synthesis of research. Leis. Sci. 1982, 5, 109-126. [CrossRef]

46. Maggs, J.Q.; Mann, B.Q.; Potts, W.M.; Dunlop, S.W. Traditional management strategies fail to arrest a decline in the catch-per-unit effort of an iconic marine recreational fishery species with evidence of hyperstability. Fish. Manag. Ecol. 2016, 23, 187-199. [CrossRef]

47. Scandol, J.P.; Holloway, M.G.; Gibbs, P.J.; Astles, K.L. Ecosystem-based fisheries management: An Australian perspective. Aquat. Liv. Resour. 2005, 18, 261-273. [CrossRef]

48. Patterson, J.J.; Smith, C.; Bellamy, J. Understanding enabling capacities for managing the 'wicked problem' of nonpoint source water pollution in catchments: A conceptual framework. J. Environ. Manag. 2013, 128, 441-452. [CrossRef] [PubMed]

49. Head, B.W. Assessing network-based collaborations: Effectiveness for whom? Public Manag. Rev. 2008, 10, 733-749. [CrossRef]

50. Dennison, W.C.; Abal, E.G. Moreton Bay Study: A Scientific Basis for the Healthy Waterways Campaign; South East Queensland Regional Water Quality Management Strategy: Brisbane, Australia, 1999.

51. Vörösmarty, C.J.; McIntyre, P.; Gessner, M.O.; Dudgeon, D.; Prusevich, A.; Green, P.; Glidden, S.; Bunn, S.E.; Sullivan, C.A.; Liermann, C.R. Global threats to human water security and river biodiversity. Nature 2010, 467, 555-561. [CrossRef] [PubMed]

52. Bunn, S.; Abal, E.; Greenfield, P.; Tarte, D. Making the connection between healthy waterways and healthy catchments: South East Queensland, Australia. Water Sci. Technol. Water Supply 2007, 7, 93-100. [CrossRef] 
53. Dickinson, J.L.; Shirk, J.; Bonter, D.; Bonney, R.; Crain, R.L.; Martin, J.; Phillips, T.; Purcell, K. The current state of citizen science as a tool for ecological research and public engagement. Front. Ecol. Environ. 2012, 10, 291-297. [CrossRef]

54. Marshall, N.J.; Kliene, D.A.; Dean, A.J. CoralWatch: Education, monitoring, and sustainability through citizen science. Front. Ecol. Environ. 2012, 10, 332-334. [CrossRef]

55. Cooper, C.B.; Dickinson, J.; Phillips, T.; Bonney, R. Citizen science as a tool for conservation in residential ecosystems. Ecosyst. Soc. 2007, 12, 11. [CrossRef]

56. Bonney, R.; Shirk, J.L.; Phillips, T.B.; Wiggins, A.; Ballard, H.L.; Miller-Rushing, A.J.; Parrish, J.K. Next steps for citizen science. Science 2014, 343, 1436-1437. [CrossRef] [PubMed]

57. Roy, H.E.; Pocock, M.J.O.; Preston, C.D.; Roy, D.B.; Savage, J.; Tweddle, J.C.; Robinson, L.D. Understanding Citizen Science and Environmental Monitoring: Final Report on Behalf of UK Environmental Observation Framework; Natural History Museum: Wallingford, UK, 2012.

58. Aceves-Bueno, E.; Adeleye, A.S.; Bradley, D.; Brandt, W.T.; Callery, P.; Feraud, M.; Garner, K.L.; Gentry, R.; Huang, Y.; McCullough, I.; et al. Citizen science as an approach for overcoming insufficient monitoring and inadequate stakeholder buy-in in adaptive management: Criteria and evidence. Ecosystems 2015, 18, 493-506. [CrossRef]

59. Lloret, J.; Zaragoza, N.; Caballero, D.; Riera, V. Biological and socioeconomic implications of recreational boat fishing for the management of fishery resources in the marine reserve of Cap de Creus (NW Mediterranean). Fish. Res. 2008, 91, 252-259. [CrossRef]

60. Papenfuss, J.T.; Phelps, N.; Fulton, D.; Venturelli, P.A. Smartphones reveal angler behavior: A case study of a popular mobile fishing application in Alberta, Canada. Fisheries 2015, 40, 318-327. [CrossRef]

61. Venturelli, P.A.; Hyder, K.; Skov, C. Angler apps as a source of recreational fisheries data: Opportunities, challenges and proposed standards. Fish Fish. 2016. [CrossRef]

62. Scott, E.L.; Prince, E.D.; Goodyear, C.D. History of the cooperative game fish tagging program in the Atlantic Ocean, Gulf of Mexico, and Caribbean Sea, 1954-1987. Am. Fish. Soc. Symp. 1990, 7, 841-853.

63. Witzell, W.N.; Scott, E.L. Blue marlin, Makaira nigricans, movements in the western North Atlantic ocean: Results of a cooperative game fish tagging program, 1954-88. Mar. Fish. Rev. 1990, 52, $12-17$.

64. Dunlop, S.W.; Mann, B.Q.; Van der Elst, R.P. A review of the Oceanographic Research Institute's Cooperative Fish Tagging Project: 27 years down the line. Afr. J. Mar. Sci. 2013, 35, 209-221. [CrossRef]

65. McPhee, D.P.; Sawynok, W.; Warburton, K.; Hobbs, S.J. The ranging movements of swallowtail dart (Trachinotus coppingeri) in Queensland and northern NSW. Proc. R. Soc. Qld. 1999, 108, 89-97.

66. Finn, P.G.; Udy, N.S.; Baltais, S.J.; Price, K.; Coles, L. Assessing the quality of seagrass data collected by community volunteers in Moreton Bay Marine Park, Australia. Environ. Conserv. 2010, 37, 83-89. [CrossRef]

67. Fonseca, M.S. Addy revisited: What has changed with seagrass restoration in 64 years? Ecol. Restor. 2011, 29, 73-81. [CrossRef]

68. Peters, J.R.; Yeager, L.A.; Layman, C.A. Comparison of fish assemblages in restored and natural mangrove habitats along an urban shoreline. Bull. Mar. Sci. 2015, 91, 125-139. [CrossRef]

69. Furukawa, K. Case studies for urban wetlands restoration and management in Japan. Ocean Coast. Manag. 2013, 81, 97-102. [CrossRef]

70. Suding, K.N. Toward an era of restoration in ecology: Successes, failures, and opportunities ahead. Annu. Rev. Ecol. Evol. Syst. 2011, 42, 465. [CrossRef]

71. McManus, P. Mangrove battlelines: Culture/nature and ecological restoration. Aust. Geogr. 2006, 37, 57-71. [CrossRef]

72. Grabowski, J.H.; Peterson, C.H. Restoring oyster reefs to recover ecosystem services. Theor. Ecol. Ser. 2007, 4, 281-298.

73. Beck, M.W.; Brumbaugh, R.D.; Airoldi, L.; Carranza, A.; Coen, L.D.; Crawford, C.; Defeo, O.; Edgar, G.J.; Hancock, B.; Kay, M.C.; et al. Oyster reefs at risk and recommendations for conservation, restoration, and management. Bioscience 2011, 61, 107-116. [CrossRef]

74. Kasoar, T.; Zu Ermgassen, P.S.; Carranza, A.; Hancock, B.; Spalding, M. New opportunities for conservation of a threatened biogenic habitat: A worldwide assessment of knowledge on bivalve-reef representation in marine and coastal Ramsar Sites. Mar. Freshw. Res. 2015, 66, 981-988. [CrossRef]

75. Ogburn, D.M.; White, I.; Mcphee, D.P. The disappearance of oyster reefs from eastern Australian estuaries-Impact of colonial settlement or mudworm invasion? Coast. Manag. 2007, 35, 271-287. [CrossRef] 
76. Ford, J.R.; Hamer, P. The forgotten shellfish reefs of coastal Victoria: Documenting the loss of a marine ecosystem over 200 years since European settlement. Proc. R. Soc. Vic. 2016, 128, 87-105. [CrossRef]

77. Schulte, D.M.; Burke, R.P.; Lipcius, R.N. Unprecedented restoration of a native oyster metapopulation. Science 2009, 325, 1124-1128. [CrossRef] [PubMed]

78. La Peyre, M.; Furlong, J.; Brown, L.A.; Piazza, B.P.; Brown, K. Oyster reef restoration in the northern Gulf of Mexico: Extent, methods and outcomes. Ocean Coast. Manag. 2014, 89, 20-28. [CrossRef]

79. Mann, R.; Powell, E.N. Why oyster restoration goals in the Chesapeake Bay are not and probably cannot be achieved. J. Shellfish Res. 2007, 26, 905-917. [CrossRef]

80. Pierson, K.J.; Eggleston, D.B. Response of estuarine fish to large-scale oyster reef restoration. Trans. Am. Fish. Soc. 2014, 143, 273-288. [CrossRef]

81. Cerco, C.F.; Noel, M.R. Can oyster restoration reverse cultural eutrophication in Chesapeake Bay? Estuar. Coasts 2007, 30, 331-343. [CrossRef]

82. Gedan, K.B.; Kellogg, L.; Breitburg, D.L. Accounting for multiple foundation species in oyster reef restoration benefits. Restor. Ecol. 2014, 22, 517-524. [CrossRef]

83. Browne, M.A.; Chapman, M.G. Ecologically informed engineering reduces loss of intertidal biodiversity on artificial shorelines. Environ. Sci. Technol. 2011, 45, 8204-8207. [CrossRef] [PubMed]

84. Perkol-Finkel, S.; Ferrario, F.; Nicotera, V.; Airoldi, L. Conservation challenges in urban seascapes: Promoting the growth of threatened species on coastal infrastructures. J. Appl. Ecol. 2012, 49, 1457-1466. [CrossRef]

85. Firth, L.B.; Thompson, R.C.; Bohn, K.; Abbiati, M.; Airoldi, L.; Bouma, T.J.; Bozzeda, F.; Ceccherelli, V.U.; Colangelo, M.A.; Evans, A.; et al. Between a rock and a hard place: Environmental and engineering considerations when designing coastal defence structures. Coast. Eng. 2014, 87, 122-135. [CrossRef]

86. Pickering, H.; Whitmarsh, D. Artificial reefs and fisheries exploitation: A review of the 'attraction versus production' debate, the influence of design and its significance for policy. Fish. Res. 1997, 31, 39-59. [CrossRef]

87. Ingram, B.A.; Hayes, B.; Rourke, M.L. Impacts of stock enhancement strategies on the effective population size of Murray cod, Maccullochella peelii, a threatened Australian fish. Fish. Manag. Ecol. 2011, 18, 467-481. [CrossRef]

88. Blount, C.; O’Donnell, P.; Reeds, K.; Taylor, M.D.; Boyd, S.; van der Walt, B.; McPhee, D.P.; Lincoln-Smith, M. Tools and criteria for ensuring stuarine stock enhancement programs maximize benefits and minimize impacts. Fish Res. 2016, 186, 413-425. [CrossRef] 